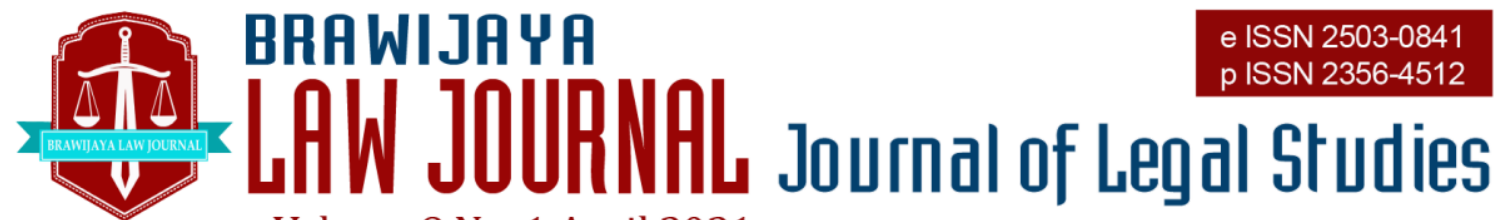

Volume 8 No. 1 April 2021

Nationally Accredited No. 30/E/KPT/2018 Dated 24th October 2018

This work is licensed under a Creative Commons Attribution-NonCommercial 4.0 International License

\title{
Alternative Dispute Resolution (ADR) Hybrid in Cameroon as a Form of Legal Protection for Consumers of Defective Products
}

\author{
Egute Matthew Amandong \\ Department of English Law, Faculty of Laws and Political Science \\ University of Yaounde Ii, Soa - Cameroon \\ Email: mathewegute@gmail.com
}

Submitted : 2021-03-25 | Accepted : 2021-04-27

\begin{abstract}
As part of the awareness creation exercise, this paper seeks to establish that consumers of defective products in Cameroon should be exposed to the various extra-judicial channels once they can be adopted by Government and through which the consumers can enforce their rights. This is known as Alternative Dispute Resolution (ADR). The paper argues that, considering the difficulties encountered by the consumer within the adversarial system, the non-judicial mechanisms are more impactful and satisfactory to consumers than the judicial. It is equally argued that the judicial mechanisms depict a certain level of risk taking, that is, the risk of winning or losing and hence going without a remedy. This risk factor is much lower in the non or extra - judicial system or mechanism which reveals that in appropriate circumstances, the producers using the good customer relation basis, are minded to compensate even where the consumer's claim is baseless. In this wise, it is therefore necessary to encourage the utilization of the extra - judicial mechanisms in resolving consumer complaints. Expediency, speed and low cost no doubt support this call.
\end{abstract}

Keywords: alternative dispute resolution; adr hybrid; legal protection; consumer of defective product.

\section{INTRODUCTION}

Over the years, litigation, a Western idea and concept of dispute resolution and justice dispensation, has held sway. The training and orientation of legal practitioners in Europe and America lend credence to this assertion. The peculiar focus or the usual call is for judicial intervention through adversarial procedure in the resolution of disputes between individuals inter se, consumers and producers, companies, as well as between individuals and the State.

With the demise of colonialism and the attainment of political independence, adjudicatory process of dispute resolution became a long lasting legacy of the British and French to the Cameroonian bi-jural legal 
system. ${ }^{1}$ Yet, evidence abounds as to the existence of acceptable traditional methods of dispute resolution in the then British and French colonies. However, the experience under colonialism and the manipulation of an average educated Cameroonian at the time, blindfolded him from realizing the beauty and wisdom behind his age - long traditional methods of resolving disputes, including disputes involving defective products $^{2}$, which predated the arrival of the British and the French in the land mass constituting the present day Cameroon. Thus, the adjudicatory system was accorded such orchestrated importance to the detriment and peril of the traditional African dispute resolution process of mediation, reconciliation, negotiation and arbitration. This paper therefore seeks to examine the general nature of the adversarial system, the historical antecedence of the modern ADR, reasons for the choice of ADR as a consumer ${ }^{3}$ redress mechanism in defective products ${ }^{4}$ related cases, hybrids of ADR.

\section{LEGAL MATERIALS AND METHODS}

This paper used normative methodology, which examines the

1 The bi-jural legal system in Cameroon is comprised of the Common Law, introduced in Anglophone Cameroon by Great Britain and the Civil Law, introduced in Francophone Cameroon by France, following the defeat of Germany in Cameroon, a former German Protectorate in 1916. This was followed by a partition of Cameroon between Great Britain and France under the supervision of the League of Nations. It is in respect of the partition that the two European Nations were able to impose their legal systems in their respective territories.

2 According to Article 1386 (4) of the French Civil Code, defective products are products that constitute imperfections that render them unsuitable for the purpose for which they were demanded.

3 Section 2 of the 2011 Cameroonian Consumer Protection Law defines a consumer as: Any person regulations or law regarding ADR and also general nature of the adversarial system, the historical antecedence of the modern ADR. It adopted the statute approach to examines relevant legal framework and also used case approach to examine more detail and deeper to help answer research problem. Moreover, the legal materials used in this paper include ADR instrument law in Cameroon and other states and also several cases regarding ADR in Cameroon.

\section{RESULT AND DISCUSSIONS The adversarial system}

The adversarial system is at the core of the common and civil law systems of civil justice as practiced in the United Kingdom and France and "received" in Cameroon. It is a colonial legacy that still pervades most commonwealth and French speaking countries.
According to Dele Peter: ${ }^{5}$
"Adversarial system is a system for the attainment of justice according to law through the intervention of a supposedly neutral third party who through the intervention of the law as a judge pronounces upon the rights, obligations and liabilities of each litigant before him. This procedure portends that justice

who uses products to meet his own needs and those of his dependents rather than to resell, process or use them within the context of his profession, or any person enjoying the services provided.

4 According to Article 1386 (4) of the French Civil Code: A defect is an imperfection that renders the product unsuitable for the purpose for which it was demanded. Defective products are products that contain vices that may or may not be hidden and the vices must render the products unsuitable or unfit for their intended purposes.

5 Dele Peters, Alternative Disputes Resolution, Published in New Perspectives in Law - Essays in honour of Honourable Justice Terna Fefa Puusu (Chief judge of Benue State - Nigeria), (2005), Published by Dee - Sage Nigeria Ltd. Lagos, at $\mathrm{p}$. 390. 
must be dispensed according to the laid down rules of the law"

The outcome of such a system is perhaps undoubtedly legal justice, justice according to the law, which may definitely not be a reflection of the social realities. The system as old as it is in Cameroon may be subjected to the following criticisms:

Firstly, apart from the fact that the search for justice is always an elusive ideal, legal justice in Cameroon with respective to relatively defective products has become more formalistic and technical and most meritorious claimants have lost their cases because of the technicalities involved as well as the lack of expertise knowledge involved in the production of some of the offensive products. To this effect, proof of fault or causation has never been easy on the part of the injured consumers and plaintiffs. For instance, in the case of Elsie Elange Ndua $v$. Brasseries du Cameroun ${ }^{6}$, the court pointed out that the victim, who was allegedly injured by the product of the defendants she consumed, ought to have carried out a laboratory analysis of the drink as proof of its defectiveness and also further scientific tests to show that what she allegedly consumed was the effective cause of her ailment and her action failed. Furthermore, in the case of Maxebong Hope Sone v. Ikoe Esoe David and Guinness Cameroon ${ }^{7}$, the plaintiff's action failed, as the court held that the allegation against the defendants could not be proved. While in the Douala Court of Appeal case of SATOM Cameroon v. G.C.E $E^{8}$, it was held inter alia that where fault cannot be established, the defendant must be exonerated from liability and the plaintiff lost

\footnotetext{
Suit No. BM/35//95 - 96 (Unreported)

Suit No. HCK /12/97 (Unreorted).

C.A. Douala : Arret No. 12/Cdu 18 Octobre, 1991.

Suit No. CASWP/14/79 (Unreported).
}

the case. In addition to the above, in Brasseries du Cameroun v. John Mokake $E_{a l i}{ }^{9}$, the Buea Court of Appeal found drinks allegedly supplied by the appellants to be defective, but nevertheless set aside the judgment of the trial court on the grounds that the respondent could not show that he actually consumed the said product.

These complexities become more chronic and costly for consumers of defective products as litigation goes up the judicial pinnacle, thereby making judicial proceedings both mysterious and daunting for most consumers. In the mist of these difficulties faced by consumers, arising from the technicalities insisted upon by the courts, we may argue that ADR as a consumer redress mechanism in Cameroon will be very imperative and thus solicited.

Secondly, in Cameroon, a litigant's success in court in trials involving defective products is again dependent on a series of variables and factors. For instance, the concept of legal practice may, to a large extent, depend on the calibre of the Attorney which a litigant can afford to pay for and hence the monetization of justice and the aphorism that justice is for the highest bidder $^{10}$. This has invariably and adversely affected the perception of the poor and the down trodden members of the society who cannot afford what it takes, in monetary terms, to obtain justice. This has led to the loss of confidence in the system. Mr. Justice Arthur Vanderbilt expressed the same view rather bluntly as follows:

"...it is the courts and not in the legislature that our citizens primarily feel the keen, cutting edge of the law. If they have respect for

10 Ayua. I.A., 'Nigerian Legal Profession : Problems and Prospects', in Ayua (ed.) Law, Justice and Nigerian Society, NIALS Commemorative Series I, (Nigerian Institute of Advanced Legal Studies, Lagos, 1995) at p. 6. 
the work of the courts, their respect for law will survive the shortcomings of every other branch of government. But if they lose their respect for the work of the courts, their respect for law and order will vanish with it to the great detriment of society" $"$.

Thirdly, it has been noticed that under the adversarial system in Cameroon, most lawyers tend to obstruct the course of justice through frequent vexatious adjournments and appeals. ${ }^{12}$ They sometimes tarnish the evidence which is favourable to the opposition while at the same time suppress evidence favourable to opponents as well as prevent the falsity of evidence on his own side to be discovered. In this wise, the adversarial system generally in Cameroon is not very perfect and to this end we call for reforms and perhaps ADR as alternative to the system most especially in the area of consumer protection law.

Lastly, the lengthy periods adopted by the courts in Cameroon in resolving product liability cases is not quite favourable to the consumer. Hence, the need for a faster means of adjudication in favour of the consumer. We may support our argument here with the case of Ntum George Nde v. Brasseries du Cameroun $^{13}$, a case considered to have exposed the waton delay orchestrated by our courts in the dispensation of justice with respect to products contaminated by foreign materials. A case that was initiated at the High Court of Limbe of the South West Region in 2001and up till 2020 it is still pending before the Supreme Court of Cameroon for final judgment. In that case,

11 Vanderbitt .A., The Challenge of Law Reform (Princeton University Press, 1955) pp $4-5$.

12 See also: Herbert Smith Freehills, A MultiJurisdictional Review: Dispute Resolution in Africa, Legal Guide Second Edition, (Herbert Smith Freehills , 2016), p 50-57, online access: the plaintiff consumed a "33 Export" drink manufactured by the defendants Brasseries du Cameroun, which drink was found to be contaminated with foreign materials. The trial court in a seasoned and sound water tight judgment found in fovour of the plaintiff. But the judgment of the High Court was reversed by the Buea Court of Appeal. Aggrieved by the judgment of the Court of Appeal, the Appellant filed an appeal at the Supreme Court in 2010 and final hearing is still pending. The burning question is, after about 20 years, is the appellant still alive and even if he is still alive, is he still interested in the case? Will he still be very healthy enough to travel to and from Yaounde when the Supreme Court shall finally commence hearing, including adjournment periods? Even at this juncture, no one knows when the Supreme Court shall be ready to hear this appeal.

In the light of the foregoing, it is arguable that the adversarial system in certain situations does not reflect the social realities expected by the consumers of defective products in Cameroon. This is due to the very lengthy periods taken by the courts in most cases within the adversarial system in rendering judgments. For, in the Ntum George Nde case discussed above, the very lengthy period taken by the courts definitely cannot meet the social realities expected by any consumer of defective products, for the adage is that "justice delayed is justice denied". In this vein, the ADR hybrid as a form of legal protection will be more realistic and acceptable because of speed and its low cost.

https://www.herbertsmithfreehills.com/sites/conte nthub_mothership/files/Guide\%20to\%20dispute \%20resolution\%20in\%20Africa_w_bookmarksv2 .pdf

13 Suit No. CASWP/5/2005 (Unreported). 
In yet another Cameroonian case Nkeh Napoleon v. Folepia Thomas and Guinness Cameroon. S.A. ${ }^{14}$, the plaintiff in early March 2000 initiated a suit against the defendants at the Bamenda Court of First Instance, claiming damages for injuries resulting from the

Consumption of a defective drink Satzenbrau beer allegedly manufactured by the defendants. It is very curious to note that up till date, the case is still pending before the trial court for hearing and it goes without saying that justice delayed is justice denied.

Considering the above listed difficulties faced by the consumers of defective products in Cameroon, ADR appears to be the only panacea or a better choice of a consumer redress mechanism. This will serve as an alternative to the traditional judicial process that will be more relevant given that its mechanisms are cheaper, more informal, quicker, more user friendly than the courts, and promote a more holistic reconciliatory approach to disputes.

\section{Historical antecedence of ADR}

The total dissatisfaction of the public with the adversarial model of dispute resolution led invariably to the evolution of the alternative mechanisms for dispute settlement. The acronym ADR means Alternative Dispute Resolution, a group of flexible approaches to resolving disputes more effective, quickly and at lower cost than going through the tedious roads of

14 Suit No. BA/52/99 - 2000(Unreported).

15 Joseph Nwazi, 'Assessing The Efficiency of Alternative Dispute Resolution (ADR) in The Settlement of Environmental Disputes in The Niger Delta Region of Nigeria', (2017) 9(3), Journal of Law and Conflict Resolution, p. 27

16 See Goldberg, et al, Dispute Resolution, $2^{\text {nd }}$ ed. (Little Brown \& Co. Boston U.S.A, 1997).

17 Law Reform Commission, Alternative Dispute Resolution: Mediation and Conciliation, (Report, Law Reform Commission, 2010), p.13 adversarial proceedings. ${ }^{15}$ It is a term which has become associated with a lot of specific dispute resolution options such as Arbitration, Conciliation, Mediation, Negotiation and a lot of other hybrid mechanisms ${ }^{16}$. Some argue that "ADR involves the assistance of a neutral third party, and which empowers parties to resolves their own disputes"17.

The historical evolution of the modern alternative movement is very instructive. Beginning in the sixties, a number of developed countries such as the United States and Australia witnessed an extra - ordinary growth of interest in alternative form of dispute resolution ${ }^{18}$. Interest increased substantially in the seventies and at the 1979 Pound Conference in Minnesota, leading jurists and lawyers came together to address popular dissatisfaction with the crowded justice system ${ }^{19}$. It was at this conference that Professor Frank. E. A. Sander, an astute crusader of alternative dispute resolution proffered a radically different vision of the American Justice System in the name and style of the "Multi - Door Court House". Professor Sander's Multi - Door Court House concept is a court - connected ADR programme, which provides a comprehensive approach to dispute resolution. The concept posits that the ideal court house is a multifaceted dispute resolution center which offers disputants a number of options or "doors" through which

18 See Dele Peters, above n 5, at p. 399.

19 See Kehinde Aina, 'The Lagos Multi - Door Courthouse and the judge: A New Beginning', (2004) Modern Practice Journal of Finance \& Investment Law MPJFIL 8 nos. 3-4 at 340; see also: Yoshai Boyarin, 'Court-Connected ADR-A Time of Crisis, A Time of Change',(2012) 95(3), Marquette Law Review, p. 996-997 
disputants may pass to get to the appropriate dispute resolution process.

In the United States and so many European countries, the use of ADR has been encouraged and has found increasing favour. There are a number of reasons for this trend. The level of litigation in the United States for instance has grown to enormous proportions and the courts are so full that very long delays in obtaining trials date are common. The costs of litigation are equally high and are not ordinarily recoverable; and very high awards are often granted, making litigation an extremely hazardous exercise ${ }^{20}$.

In a bid to over-come the above listed problems, the United States and many European countries adopted the ADR system due to its low cost, speed, less complexity and satisfaction, all to the advantage of the plaintiff ( in our case, the consumer of defective products).

Similar problems are being faced by disputants in Cameroon, including consumers of poor quality products and we intend to argue in this paper that an adoption of the ADR system will serve as a panacea as well as a choice of consumer redress. In a bid to upgrade the ADR system and make it more meaningful, Cameroon with 16 other African countries in 1993 enacted the OHADA Treaty (also known as the Organization for the Harmonization of Business Law in Africa) in Port Louis- (Mauritius), better known by its French Acronym as L'Organisation pour L'Harmonisation en Afrique du Droit des Affaires. The Council

20 Brown .H. \& Marriott : ADR Principles and Practice, (1993), Sweet \& Maxwell at 9

21 Member countries include; Benin, Burkina Faso, Cameroon, Central African Republic, Chad, Comoros, Congo, Democratic Republic of Congo, Equatorial Guinea, Gabon, Guinea Bissau, Cote d'Ivoire, Mali, Niger, Senegal and Togo.

22 The OHADA Uniform Act on Mediation, adopted on $23^{\text {rd }}$ November 2017 in Conakry (Guinea), entered into force on March 2018. of Ministers of $\mathrm{OHADA}^{21}$ adopted three major tools aimed at favouring alternative dispute resolution mechanisms in African countries - (i) a new Uniform Act on Mediation $^{22}$, (ii) a Revised Uniform Act on Arbitration $^{23}$, and (iii) undated Rules of Arbitration of Common Court of Justice and Arbitration $(\mathrm{CCJA})^{24}$. OHADA is an international organization composed of 17 West and Central African Countries whose goal is to promote regional economic development through the harmonization of its member states business laws. Harmonization is mainly achieved through the so called Uniform Acts which compiled all relevant legal norms in specific areas of business. ${ }^{25}$ OHADA relies on specific institutions such as the CCJA which is an arbitral institution and assumes the role of a Supreme Court in all disputes regarding the application of the Uniform Acts. It should be noted that its headquarters is in Abidjan and ordinary litigants and consumers in Cameroon will hardly have access to this institution. Thus, only big companies and entrepreneurs can easily have access to the CCJA. To resolve this difficulty, litigants of defective products in Cameroon will be more exposed to ADR mechanisms which are locally provided. The ADR mechanisms equally provided by the OHADA Treaty are more inclined to business in general rather than issues of consumer protection involving defective products between local consumers and producers within the country.

23 The Revised OHADA Uniform Act on Arbitration was adopted on the $23^{\text {rd }}$ of November 2017, replacing the initial Text of March 1999.

24 The Revised CCJA Rules on Arbitration was adopted on the $23^{\text {rd }}$ of November 2017.

25 It should be noted that the OHADA Treaty was ratified in Cameroon by a presidential Decree No. 96/177 of $5^{\text {th }}$ September 1996 after the authorization of the National Assembly through Law No. 94/4 of August 1994. 
In addition to the OHADA Treaty, Cameroon has two other local arbitration institutions or centers - GICAM $^{26}$ and the Chamber of Commerce. GICAM is based in Douala and it is the foremost arbitration institute in the country and most of the arbitration disputes are between companies. While issues of defective products mostly involve individuals (consumers) and producers, their disputes are often settled by the ordinary courts of the land. Because of the congestion of matters in the ordinary courts and the general problems encountered within the adversarial system of adjudication, our main objective in this write-up is geared towards tracing other alternative means of settling defective products related disputes between consumers and producers. Here, we are referring to alternative means of settling disputes. These are possible and realistic mechanisms that will go a long way to assist a litigant of defective related products in Cameroon to obtain satisfactory results.

\section{Reasons for the choice of ADR as a consumer redress mechanism for defective products in Cameroon.}

It is in the search of alternatives to the traditional judicial process that ADR becomes relevant given that its mechanisms are cheaper, more informal, quicker, more user-friendly than the courts, and promote a more holistic, reconciliatory approach to disputes. The argument for the adoption of ADR, therefore, centers on the fact that it will give consumers of defective products in Cameroon an involvement in the process of resolving their disputes that is not

26 Centre d'arbitrage du Groupement interpatronal du Cameroun.

27 See also the views of The Rt. Hon. The Lord Mackay of Clashfern, The Administration of Justice: The 1993 Hamlyn Lectures (Stevens \& Sons/Sweet \& Maxwell: London, 1994) pp 69-70. possible in a public, formal and adversarial justice system perceived to be dominated by the abstruse procedures and recondite language of law ${ }^{27}$. Consequently, the ADR system offers choice, that is, the choice of procedure, method, cost representation and location ${ }^{28}$. We agree with the view expressed by $\operatorname{Ladan}^{29}$, Where he says 'ADR' is "a useful shorthand expression as long as it is understood to refer to a system of multioption justice in which a wide range of dispute resolution processes are available to parties in the public system".

It is equally submitted that $\mathrm{ADR}$ is perhaps better understood when viewed as "African Dispute Resolution". This would invariably refer to diverse party-friendly, cost effective and non adversarial methods of dispute settlement in the traditional African setting as opposed to litigation - centered approach of the West. These diverse African Dispute Resolution Methods such as negotiation, conciliation and mediation will help to maintain peace and create an enabling environment for good relationship and neighborliness and maintain on-going relationships between consumers and producers in Cameroon.

From the foregoing, the ADR mechanisms are more common with non judicial institutions like trade and professional associations or with regulatory agencies like consumer control bodies. These consumer control bodies are less common with the courts. If any, their effectiveness may be thwarted by the court. For example, in the Nigerian case of Commercial Assurance Ltd. v. Ali ${ }^{30}$, the Court of Appeal

28 Ibid at p. 70.

29 'Alternative Dispute Resolution in Nigeria: Benefits, Processes and Enforcement', Current Themes in Nigeria Law, at 248.

30 (1986) 3 NWLR (pt. 29) 404. 
held that a contentious enforcement of an arbitral award should be by way of a writ of summons rather than the simple and quicker originating summons. The advantage of speed which the arbitral award sought to achieve was consequently defeated. In this vein, the call for $\mathrm{ADR}$ mechanisms in resolving defective products related matters becomes imperative in Cameroon. Finally, ADR mechanisms could also be very useful to the producers in that cases involving defective products which could have damaging effects if heard in the open courts are decided under restricted and closed doors not involving the public.

\section{Hybrids of Alternative Dispute Resolution}

\section{a. Negotiation}

Negotiation which is from the Latin expression "negotiatus", is perhaps the commonest of the diverse methods of dispute resolution. It is also the oldest of these dispute resolution processes. Usually, when deterioration becomes noticeable in a relationship and as long as the parties concerned are still communicating, the situation could be stopped from developing into a full blown dispute. Even at a point of full blown dispute, in most cases, efforts are sometimes made to resolve that dispute through "talking to each other", that is, negotiating.

On the other hand, negotiation seeks to establish the state of liability in issue but with a view to realigning such liabilities. There is no dispute as to the existence, nature or

31 For more on this, see the Article Resolving Consumer Disputes: Alternative Dispute Resolution and the Court System available at < https://assets.publishing.service.gov.uk> See also Office Fair Trading 1267. 2010 Mapping UK Consumer redress: A summary guide to dispute resolution system at 1 .

32 Bryan A. Garner, Black's Law Dictionary, $10^{\text {th }}$ ed.(Thomson Reuters Publishers U.S.A., 2014) at p. 1200 . quantum of the liability. All that the debtor wants is to realign or negotiate how to meet his liability. The appropriateness of this mechanism will depend on the circumstances of each case. For instance, where a consumer claim is for a sum certain ${ }^{31}$ or for a replacement of the defective product, it does appear that negotiation will be the most ideal. Thus, according to Black's Law Dictionary, "negotiation is a consensual bargaining process in which the parties attempt to reach agreement on a disputed or potentially disputed matter" 32 .

Negotiation is thus a voluntary unstructured and usually private process through which the consumer and the producer already in dispute can reach an agreement for the resolution of their disagreement. ${ }^{33}$ It is usually an informal dispute resolution process in which disputants have a firm and total control of the entire arrangement. The success or failure of this process, more often than not depends entirely on the disputants themselves since the process offers an opportunity for them to talk on one on one basis. A common feature of negotiation is the absence of a third party facilitator. Disputants personally present their case, marshal arguments and lead evidence. They may or may not appoint individuals or professionals such as lawyers to represent their interest ${ }^{34}$. The totality of the foregoing attributes of this dispute resolution hybrid has endangered the explanation of negotiation as the fastest, least expensive, most private, less complicated and most

33 See the Cameroonian case of Kimbeng Nde Richard v. Guinness Cameroon .S.A., Suit No. $\mathrm{HCB} / 42 / 03$ - 04 (unreported). In that case, the plaintiff consumed a defective product - Guinness Drink, produced by the defendants. Curiously, the parties after exchanging the statement of claim and statement of defence opted for an amicable settlement of 1.000 .000 FCFA through negotiation.

34 See generally Goldberg, et al, above n 16 
party-control oriented process. This of course can rekindle consumers to be more interested in product liability related issues and cases, owing to the long and expensive procedures often adopted by the courts.

\section{b. Mediation}

Mediation on the other hand is negotiation carried out with the assistance of a neutral third party. It is a voluntary process, which offers disputants meaningful and creative solution at a fraction of the cost of the litigation system $^{35}$. Thus, where relationships are involved, the best course will be mediation since that targets the restoration of strained relationships.

In other words, mediation is a facilitative process in which an injured consumer of a product and the manufacturer can engage the assistance of a neutral third party who acts as a mediator in their dispute. The neutral third party has no authority to make any decisions, which are binding on them, but uses certain procedures, techniques and skills to help them to negotiate a resolution of their dispute by agreement without adjudication ${ }^{36}$.

Good mediation attempts to overcome negotiation impasse by overcoming barriers to successful negotiation and the neutral third party does not have any authority to make any decision or award for the parties. Indeed, that is not the duty of the mediator ${ }^{37}$. Even where the mediator expresses a view about

35 Macforlane J. ; An Alternative to What : The Mediation Alternative, (Cavendish Publishing Ltd, 2004), at p. 1

36 Brown H. \& Marriott, ADR Principles and Practice, (Sweet \& Maxwell, 1993) at 9

37 See Macforlane j., above n 35, p. 7.

38 See Mackie, Miles and Marsh, Commercial Dispute Resolution, An ADR Practice Guide, (Butterworths, 1995), at p. 9.

39 See Abany Chantal Akwembe, Alternative Dispute Resolution (ADR) as a Mechanism of Peace in the merits of the dispute, that opinion is not binding on the disputants and in no circumstances would a mediator have the power to impose his view on the disputants. Indeed, any such would be contrary to the spirit of mediation, which is inherently consensual $^{38}$. In fact, like many other hybrids of ADR, speed and low cost are some of the advantages of mediation. For instance, in 2003, Ghana held its first mediation week in which about 300 cases pending in some courts in Accra were mediated within 5 days $^{39}$ while in 2007 , over 155 commercial and family cases from 10 District courts in Accra were mediated over 4 days. ${ }^{40}$

\section{c. Conciliation}

Conciliation is the settlement of a dispute in an agreeable manner. This method of settlement could be more suitable with cases involving petty consumer claims usually undertaken by regulatory consumer protection bodies ${ }^{41}$. Practical examples are encountered in Nigeria every year. For example, in 1988, of the 16 consumer complaints treated by SON, the remedy of replacement was obtained in 3 cases $^{42}$. In 1990, replacement was obtained in 2 of the 17 cases treated $^{43}$. And in 1991, replacement was obtained in 3 of the 19 cases treated ${ }^{44}$. Such bodies do not possess the power to impose fines but could order for a refund of money where the product in question is defective. On the other hand, they can also

Africa, https://www.commosensemedia.org/appreviews/the-free-dictionary-by-farlex

40 Ibid

41 See the activities of SON (Standard Organization of Nigeria) and the successes recorded with respect to petty consumer complaints in Nigeria.

42 Complaints 2, 5 and 15 of the SON Annual Report 1988 at pp. 19, 20 and 25 respectively.

43 Complaints 13 and 14 of the SON Annual Report 1990 at p. 23.

44 Complaints 15, 17 and 19 of the SON Annual Report 1991 at pp. 60, 61 and 62 respectively. 
negotiate for a replacement of the defective product or item as illustrated above. Hence, conciliation is aimed at trying to get disputants to stop arguing and agree.

It is also a process in which a neutral person meets with the parties to a dispute and explores how the dispute might be resolved. It is a relatively unstructured method of dispute resolution by a third party who facilitates in our case, communication between the consumer and the producer, manufacturer or service provider in an attempt to help them settle their differences.

\section{d. Arbitration}

It is a dispute resolution process in which the consumer and the producer may decide to choose one or more neutral third parties to make a final and binding decision in resolving their dispute. The parties to the dispute may choose a third party directly by mutual agreement or indirectly, such as by agreeing to have arbitration organization selects the third party.

For arbitration, it does seem that it comes in useful where the dispute in issue involves a large number of consumers especially if such warrants the use of class actions ${ }^{45}$. Here, given that the stakes would be high, arbitration is a viable option ${ }^{46}$. Relationships may not be involved here and it may be risky and costly to subject the arbitral award to the whims and caprices of the parties. Arbitration, which ensures that the award is binding, is undoubtedly, ideal.

\section{e. Mini - Trial}

Mini-trials are not common in most African countries including Cameroon. But its practice in a bid to resolve defective products related issues could be a welcome idea due to its recorded successes in saving both time and money ${ }^{47}$. Thus, it is another ADR mechanism process whereby counsel for each disputant makes a presentation on the legal, factual as well as evidentiary stance in support of his case. This proceeding is usually before an official with authority to effect settlement of dispute, and a third party neutral who serves as adviser. Through this presentation, all disputants in a case are afforded an opportunity to assess the strength and weakness of their position and thereby decide whether or not to settle out of court or resort to adversarial procedure. If at the end of their presentation the parties are unable to agree on settlements, the third party neutral adviser evaluates the case for both sides by examining the facts as presented, the evidence tendered and the position of the law on the issues. Therefore, the advisor gives an opinion, which is strictly speaking not binding on the disputants. This opinion, which is usually a reflection of the probable outcome should the disputants go to a full trial often encourage the disputants to go into further confidential settlement negotiations in an attempt to reach a mutually acceptable agreement.

In all, the idea behind the mini - trial mechanism is that the parties can resolve a defective product related issue on their on more efficiently if litigant representatives with settling authority are educated about the strengths and weaknesses of each side, giving

Policy, (Rekon Books Ltd. - Abuja Nigeria, 2005) at 359.

47 See Alfred. C. Aman Jr. \& William.T. Mayton, Administrative Law, $2^{\text {nd }}$ ed. (2001) at p. 291.

46 For more on this, see Benedict Bakwaph Kanyip, Consumer Protection in Nigeria Law, Theory and 
summary presentations of their cases under the eye of a jointly selected neutral advisor. After each case is presented, the mini- trial is confidential and non-binding. Usually, no transcript is made of the proceeding.

\section{f. Rent - a-judge}

Rent - a - judge, as a dispute resolution mechanism including disputes involving defective products appears to be more popular and associated with the United States dispute resolution environment ${ }^{48}$. The procedure is indeed now recognized by legislation in that jurisdiction. Even though associated with the United States, the mechanism could also be experimented in Cameroon, as well as extended to suits involving defective products. This will ease tension between the disputants as well as reduce the cost of litigation. It is thus a process through which the court, on stipulation of the parties, can refer a pending law suit to a private neutral party for trial with the same effect as though the case were tried in the court room before a judge. The verdict of the process can be appealed through the regular court appellate system. Where the verdict of the process is not appealed, the parties will be more satisfied due to speed, low costs and less complexity of the litigation process. For it to work in Cameroon, the judicial system which is currently bi-jural must be re-organized and harmonized.

\section{g. Facilitation}

This is a collaborative process used to help a group of individuals or parties, with divergent views, in a bid to achieve a goal or complete a task to the mutual satisfaction of

48 See Dele Peters, above n 5, 403.

49 The complex issues in our situation could be issues involving the quality, sample and fitness for the the participants. The facilitator functions as a neutral process expert and avoids making substantive contributions. The task of the facilitator is to help bring the parties to a consensus on a number of complex issues ${ }^{49}$. This is possible where a group of people is suffering from a common problem resulting from the consumption of a defective product. For instance, dirty water supplied to a village and a large number of the people are sick following the consumption of the dirty water. The action commonly required here is "class action".

\section{h. Fact finding}

Fact finding as a dispute resolution process is often used mostly in the public sector collective bargaining. This has been practiced in Cameroon for quite some years even though the recommendations of the fact finders have not often been published nor implemented and thus not binding on the parties. Despite this, it will still be considered as a viable mechanism of ADR in matters involving defective products. This is probably possible where a large sector or a group of the public for instance, is injured by a particular product due to its defectiveness. The China 2008 Tainted Milk Scandal presents a good example. In 2008, over 22 dairy companies in China manufacturing infant power milk used melamine, a chemical used in the manufacturing of fertilizers and plastics with the intention of boosting the protein content of the milk. Unfortunately, over 300000 infants became sick ${ }^{50}$ after consuming the defective milk, with six deaths recorded. The issue here is that aside from the proceedings which were initiated by the court against the companies, a Fact

purpose of the goods, as well as issues linked with the compensation of victims.

50 Most of them suffer from Kidney stones problem which kidney stones are also rear in children. 
Finding Commission was also set up and far reaching recommendations were also made to the parties involved. Generally, the Fact Finder does not have the power of either a judge or an arbitrator. Thus, he cannot make a binding decision for the parties. Rather, the Fact Finder, drawing on both the information provided by the parties and research findings of his own efforts, makes recommendations to the parties for the resolution of the dispute between them. Although his recommendations are not binding on the parties, one important advantage of this mechanism is that, it has capacity to pave the way for further negotiations and mediations.

\section{i. $\quad$ Med - Arb}

This is an innovation in dispute resolution process. It is not common in Africa, Cameroon inclusive. But it can serve as a veritable mechanism of ADR in Cameroon in the resolution of disputes involving defective products if the judicial system is well structured and Government and its administration well organized. By this mechanism, the Med-Arbiter is authorized by the parties to serve first as a mediator and secondly as an arbitrator. When the MedArbiter serves as an arbitrator, he is given other powers to resolve any issues not resolved through mediation. Thus, Med-Arb is often resorted to so as to resolve all outstanding issues not resolved during mediation process.

\section{j. The Multi - Door Courthouse (MDCH)}

The Multi-Door Courthouse concept is the idea of an American Professor E.A. Sander ${ }^{51}$. It is a proposal to offer a variety of dispute resolution series in one place with a single intake desk, which will screen clients. The idea is one which seeks to radically change the traditional conception of the court as the only "door" to getting justice. Instead by this mechanism, other "doors" are created to which disputants could access the court and hence justice. These other "doors" include arbitration, fact-finding and mediation. An adoption of the Multi - Door Courthouse mechanism in Cameroon will be a welcome issue to consumers of defective products whose complaints are sometimes not promptly attended to due to the congestion of the cases within the regular courts, thus resulting to delays in rendering judgments. To Professor Sander, dispute resolution mechanisms such as negotiation, mediation, arbitration and other arbitration hybrids like early natural evaluation (ENE) can be fused with the existing court system and, its procedural rules adopted; thereby practically altering the existing structures, rules and composition of the existing court system. Professor Sander's idea envisioned an institutionalized system which combines Dispute Resolution mechanisms with the age long litigation process ${ }^{52}$. Nigeria in a bid to solve the congestion problem in courts has created two Multi-Door Courthouses -the Lagos Multi-Door Courthouse and the Abuja Multi-Door Courthouse. A trail by Cameroon as well must surely improve the settlement of

37(3) Catholic University Law Review, available at $<$ https://scholarship.law.edu $>$

52 See Oyeniyi Ajigboye, 'The Concept of MultiDoor Courthouse in Nigeria : Rethinking Frank Sander's Concept', (2014) SSRN Electronic Journal, <https://ssrn.com/abstract=2525677> also https://www.researchgate.net>
1 See Frank E.A. Sander, Varieties of Dispute Processing in The Pound Conference: Perspective on Justice in the Future, (A Leo Levin and Russell Wheeler eds. 1979), 64, 83-84. See also https://www.pon.harvard.edu>daily ; Gladys Kessler and Linda J. Finkelstein, (1988) 'The Evolution of a Multi-Door Courthouse', (1988) 
dispute system in general, not leaving out disputes involving defective products.

This will only be possible if the judicial system is restructured, as well as effect an extensive harmonization of the common law and civil law rules.

\section{CONCLUSION}

On a final note, we summit that as beautiful and efficacious as the ADR hybrids are, they are not the "panacea" to all kinds of disputes involving defective products. Consequently, there are certain classes or types of dispute which can only be adjudicated upon, by the courts. For instance, where the dispute warrants a definitive interpretation of the law or a constitutional interpretation, then such a dispute must only be decided by the court or through the adversarial system.

Furthermore, where the dispute involves the breach or the abuse of the fundamental rights of the consumer, then such a dispute will hardly be settled by any of the ADR hybrids. It is equally important to note that where governmental authorities or agencies must be held accountable, then any of the ADR hybrids cannot be applied.

Lastly, a defective product liability related case based on criminal law is not suited for any of the ADR processes. For instance, where the manufacturer intentionally adulterates any foodstuff whether for human or animal consumption, or beverage or medicinal substances contrary to s.258 (1) of the Penal Code, then the matter must only be tried by a criminal court of competent jurisdiction. Moreover, whoever gives false information on the quality of technology, goods or services supplied to a consumer contrary to the provisions of $\mathrm{s} .32$ (1) of the 2011 Cameroonian Consumer Protection Law is deemed to have committed a crime and such a suit will not be suitable for any of the ADR mechanisms..

Thus, whatever may be the virtue of ADR option, a note of caution must be sounded against its uncritical transposition into the civil justice system without first curing the existing defects in the system. The clamour for the ADR option in Cameroon is certainly influenced by the problems Cameroonians perceive in the current civil justice system which are the problems of formality, lack of speed, high costs and complexity of the litigation process. The question then becomes whether the ADR option can be applied without necessarily yielding to these same pressures or problems? For instance, a system of ADR where the involvement of legal professionals is integral to successful resolution will simply be a parallel to the current system, and will therefore, accrue the very problems of excessive legalism and delay which underlie calls for change. Thus, the Rt. Hon. The Lord Mackay of Clashferm has consequently advised that rather than simply replacing current procedures with new ones, we must continue to look into the causes of the problems and attempt to solve them. Otherwise, we shall merely be papering over the cracks in the current system, rather than treating the factors which cause them.

On the whole, the choice of a consumer redress mechanism is a choice between judicial and non-judicial mechanisms. It is arguable that the non judicial mechanisms are more impactful and satisfactory to the consumers than the judicial. The justification here is that judicial mechanisms depict a certain level of risk taking - the risk of winning or losing and hence going without a remedy as in the Cameroonian cases of Ntum 
George Nde v. Brasseries Du Cameroun ${ }^{53}$, Elsie Elange Ndua v. Brasseries du Cameroun $^{54}$, and John Mokake Elali v. Brasseries du Cameroun ${ }^{55}$. In all these cases, the plaintiffs who were allegedly injured by the products of the defendants lost their cases on the grounds that, they had failed to carry out laboratory analysis of the drinks as proof of their defectiveness and also further scientific tests to show that what they allegedly consumed was the effective cause of their ailments. In other words, no nexus was established between their ailments and the allege products they consumed.

This risk factor is much lower in the non - judicial mechanisms which reveal that in appropriate circumstances, producers using the good customer relation basis, are often minded to compensate even where the consumer's claim is baseless. However, with adversarial system, the effect is that, the loser is minded to delay the implementation of the decision of the court through appeals and other tactics of obstruction. However, under the non - judicial mechanisms, these obstructive tactics are less prominent as the parties most often agree on the resolutions adopted to deal with the complaint in issue. On this basis, we hereby advocate that it is necessary to encourage the utilization of the non - judicial mechanisms in resolving consumers' complaints. Expediency, speed and low cost no doubt support this call. However, the ADR mechanisms will not be quite smooth as discussed above. Firstly, the lack of professional mediators in Cameroon well-trained and available for amicable dispute settlement will be a major obstacle. Secondly, there are no mediators accredited to courts to be designated and there is no clear status for mediators or conciliators. In some cases, lawyers and judges may do out of court amicable settlement in their Chambers in the form of mediation and reconciliation. Despite these isolated settlement procedures, the issue of professionalism remains unresolved.

\section{REFERENCES}

\section{Book}

A., Vanderbitt, The Challenge of Law Reform (Princeton University Press, 1955)

Aman, Alfred. C. Jr. \& William.T. Mayton, Administrative Law, $2^{\text {nd }}$ ed. (2001)

Ayua (ed.) 'Nigerian Legal Profession: Problems and Prospects', in Ayua (ed.) Law, Justice and Nigerian Society, NIALS Commemorative Series I, (Nigerian Institute of Advanced Legal Studies, Lagos, 1995).

Garner, Bryan A., Black's Law Dictionary, $10^{\text {th }}$ ed.- (Thomson Reuters Publishers U.S.A., 2014)

Goldberg, et al, Dispute Resolution, $2^{\text {nd }}$ ed. (Little Brown \& Co. Boston U.S.A, 1997)

H., Brown \& Marriott : ADR Principles and Practice, (1993), Sweet \& Maxwell

J. Macforlane, An Alternative to What : The

Mediation Alternative, (Cavendish Publishing Ltd, 2004)

Kanyip, Benedict Bakwaph, Consumer Protection in Nigeria Law, Theory and Policy, (Rekon Books Ltd. - Abuja Nigeria, 2005)

Mackie, Miles and Marsh, Commercial Dispute Resolution, An ADR Practice Guide, (Butterworths, 1995)

Peters, Dele, Alternative Disputes Resolution, Published in New Perspectives in Law - Essays in honour

53 Suit No. CASWP/5/2005 (Unreported).

54 Suit No. BM/35/95-96 (Unreported) 
of Honourable Justice Terna Fefa

Puusu (Chief judge of Benue State -

Nigeria), (2005), Published by Dee -

Sage Nigeria Ltd. Lagos.

Sander, Frank E.A., Varieties of Dispute

Processing in The Pound Conference:

Perspective on Justice in the Future,

(A Leo Levin and Russell Wheeler eds. 1979), 83-84

The Rt. Hon. The Lord Mackay of Clashfern,

The Administration of Justice: The 1993 Hamlyn Lectures (Stevens \& Sons/Sweet \& Maxwell: London, 1994)

'Alternative Dispute Resolution in Nigeria:

Benefits, Processes and Enforcement',

Current Themes in Nigeria Law,

\section{Journals and Reports}

Aina, Kehinde, 'The Lagos Multi - Door Courthouse and the judge: A New Beginning', (2004) 8 nos. 3-4 Modern Practice Journal of Finance \& Investment Law MPJFIL at 340

Boyarin, Yoshai , 'Court-Connected ADR-

A Time of Crisis, A Time of Change',(2012) 95(3), Marquette Law Review, p. 996-997

Freehills, Herbert Smith, A MultiJurisdictional Review: Dispute Resolution in Africa, Legal Guide Second Edition, (Herbert Smith Freehills , 2016), p 50-57, online access:

https://www.herbertsmithfreehills.com /sites/contenthub_mothership/files/Gui de\%20to\%20dispute\%20resolution $\% 2$ 0in\%20Africa_w_bookmarksv2.pdf

Kessler, Gladys and Linda J. Finkelstein, (1988) 'The Evolution of a Multi-Door Courthouse', (1988) 37(3) Catholic University Law Review.

Law Reform Commission, Alternative Dispute Resolution: Mediation and
Conciliation, Report, Law Reform Commission, 2010

Nwazi, Joseph, 'Assessing The Efficiency of Alternative Dispute Resolution (ADR) in The Settlement of Environmental Disputes in The Niger Delta Region of Nigeria', (2017) 9(3),Journal of Law and Conflict Resolution, 26-41

Office Fair Trading 1267, 2010 "Mapping UK Consumer redress: A summary guide to dispute resolution system", acessed on https://webarchive.nationalarchives.g ov.uk/20131101170541/http://oft.gov. uk/shared_oft/general_policy/OFT126 7.pdf

Oyeniyi, Ajigboye, 'The Concept of MultiDoor Courthouse in Nigeria : Rethinking Frank Sander's Concept', (2014) SSRN Electronic Journal, , https://ssrn.com/abstract $=2525677$

Resolving Consumer Disputes: Alternative Dispute Resolution and the Court System available at < https://assets.publishing.service.gov.u $\mathrm{k}>$

\section{Regulations}

The French Civil Code,

The 2011 Cameroonian Consumer Protection Law.

The OHADA Uniform Act on Mediation, adopted on $23^{\text {rd }}$ November 2017 in Conakry (Guinea), entered into force on March 2018.

The Revised OHADA Uniform Act on Arbitration was adopted on the $23^{\text {rd }}$ of November 2017, replacing the initial Text of March 1999

The Revised CCJA Rules on Arbitration was adopted on the $23^{\text {rd }}$ of November 2017 Cameroon presidential Decree No. 96/177 of $5^{\text {th }}$ September 1996 after the 
authorization of the National Assembly through Law No. 94/4 of August 1994

\section{Cases}

Suit No. BM/35//95 - 96 (Unreported)

Suit No. HCK /12/97 (Unreorted).

C.A. Douala : Arret No. 12/Cdu 18 Octobre, 1991.

Suit No. CASWP/14/79 (Unreported).

Suit No. CASWP/5/2005 (Unreported).

Suit No. BA/52/99 - 2000(Unreported).

the Cameroonian case of Kimbeng Nde

Richard v. Guinness Cameroon .S.A., Suit No. HCB/42/03 - 04 (unreported)

Complaints 2, 5 and 15 of the Standard Organization of Nigeria Annual Report 1988 at pp. 19, 20 and 25 respectively.

Complaints 13 and 14 of the SON Annual Report 1990 at p. 23.

Complaints 15, 17 and 19 of the SON Annual Report 1991 at pp. 60, 61 and 62 respectively.

\section{Internets}

Abany Chantal Akwembe, "Alternative Dispute Resolution (ADR) as a Mechanism of Peace in Africa", https://www.commosensemedia.org/a pp-reviews/the-free-dictionary-byfarlex 